\title{
UNESCO WORLD KARST NATURAL HERITAGE SITES: GEOGRAPHICAL AND GEOLOGICAL REVIEW
}

\begin{abstract}
The paper is devoted to the review of the World Karst Natural Heritage and the perspectives of such new properties in the Russia. Presently there are 37 World Karst Natural Heritage sites on the globe; 34 of them have the natural heritage and 3 sites have the mixed, natural-cultural significance. The World Karst Heritage distribution by the countries and by parts of the world was analyzed. A brief description of outstanding universal value of the "Lena Pillars Nature Park", being currently the only Russian karst area nominated at the List of World Natural Heritage by a specific type of the karst ground frozen karst, was given. The necessity of the new World Karst Heritage properties characterizing by the karst development in sulfate and salt rock sites are considered. The karst areas, located in extreme (cold or arid) climate conditions, are in the focus of separate attention.
\end{abstract}

KEY WORDS: karst, world heritage properties, geological conditions, climatic peculiarities, perspective nominations.

CITATION: Elena Trofimova (2018) Unesco World Karst Natural Heritage Sites: Geographical And Geological review. Geography, Environment, Sustainability, Vol.11, No 2, p. 63-72

DOI-10.24057/2071-9388-2018-11-2-63-72

\section{INTRODUCTION AND BACKGROUND}

The identification, protection and preservation of natural and cultural heritage having the outstanding universal significance for the humanity are the one of the United Nations Educational, Scientific and Cultural Organization (UNESCO) objectives. This idea was the basis for the international «Convention for the protection of the world cultural and natural heritage» signed in 1972. Cultural heritage includes «monuments, groups of buildings and sites with historical, aesthetic, archaeological, scientific, ethnological and anthropological value» (World Heritage... 2005); and "outstanding physical, biological and geological formations, habitats of threatened species of animals and areas with scientific, conservation or aesthetic value" (World Heritage... 2005) are referred to the natural heritage.

Currently the Convention has been joined by more than 190 countries, and the World Heritage Fund, operating under the auspices of the Convention, assists to States parties in the World Heritage Sites identification, protection and development.

The aim of this paper is to present the review of the World Karst Natural Heritage and the conditions in which the unique outstanding karst is developed as well as to indicate the perspectives and necessity of the new Russian karst nominations preparation. 


\section{THE WORLD KARST HERITAGE DISTRIBUTION ON THE GLOBE}

Among the natural sites, inscribed on the World Heritage List and having the high natural or natural-cultural (mixed) status (in total 241 sites as of January 1, 2018), a special group is formed by the 37 karst properties (Fig. 1, Table 1) (Gunn 2004; Williams 2008; Trofimova and Hada 2016; etc.). Such large number of karst properties described by the universal significance is defined by a wide spread of karstic rocks (limestone, dolomite, etc.): nearly $30 \%$ of continental surface is characterized by the conditions of karst development.
Thirty-four World Karst Heritage sites are distinguished by their natural properties. The picturesque canyons, profound karstholes (Fig. 2), blue-eyed karst springs as well as the enormous underground systems are preserved here. Three karst properties are determined by a mixed (natural and cultural) status: the temples, monuments, etc. referring to the different stages of contemporary civilization development and coupled with the caves where the priceless archaeological and paleontological material was found.

Nahanni National Park (Canada) (18, here and in the rest of the text the number $(X)$ in

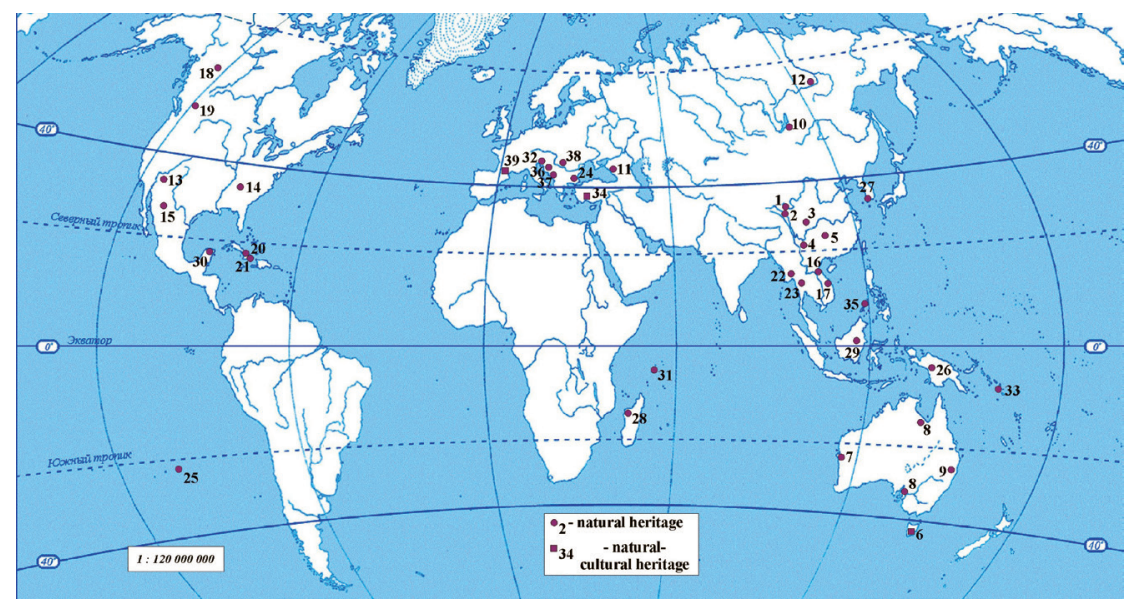

Fig. 1. World Karst Heritage

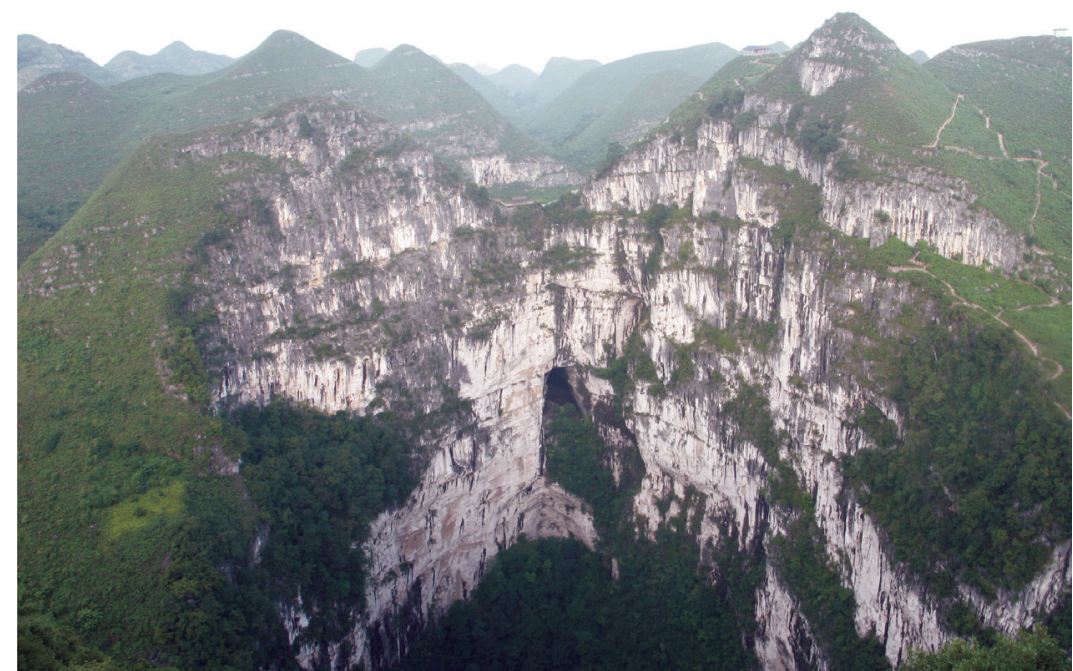

Fig. 2. Karsthole of Leye, Guangxi, South China Karst (5) (photo Y. Zhang) 
Table 1. World Karst Heritage

\begin{tabular}{|c|c|c|c|c|c|c|c|c|}
\hline \multirow[b]{2}{*}{ № } & \multirow[b]{2}{*}{ Country } & \multirow[b]{2}{*}{ Heritage properties } & \multirow{2}{*}{$\begin{array}{l}\text { Lithological } \\
\text { conditions }\end{array}$} & \multirow{2}{*}{$\begin{array}{l}\text { Climatic } \\
\text { type }\end{array}$} & \multicolumn{2}{|c|}{ Type of heritage } & \multirow{2}{*}{$\begin{array}{c}\text { Date of } \\
\text { inscription }\end{array}$} & \multirow{2}{*}{$\begin{array}{c}\text { Protected } \\
\text { area, ha }\end{array}$} \\
\hline & & & & & Natural & $\begin{array}{l}\text { Natural- } \\
\text { Cultural }\end{array}$ & & \\
\hline 1 & China & $\begin{array}{l}\text { Jiuzhaigou Valley } \\
\text { Scenic and Historic } \\
\text { Interest Area }\end{array}$ & L, D & $\mathrm{Cw}$ & + & & 1992 & 72000 \\
\hline 2 & & $\begin{array}{l}\text { Huanglong Valley } \\
\text { Scenic and Historic } \\
\text { Interest Area }\end{array}$ & L, D & $\mathrm{CW}$ & + & & 1992 & 60000 \\
\hline 3 & & $\begin{array}{l}\text { Wulingyuan Valley } \\
\text { Scenic and Historic } \\
\text { Interest Area }\end{array}$ & L & Cf & + & & 1992 & 26400 \\
\hline 4 & & $\begin{array}{l}\text { Three Parallel } \\
\text { Rivers of Yunnan } \\
\text { Protected Areas }\end{array}$ & $L, D$ & $\mathrm{Cw}$ & + & & 2003 & 1700000 \\
\hline 5 & & South China Karst & L & Cf & + & & 2007 & 49537 \\
\hline 6 & Australia & $\begin{array}{l}\text { Tasmanian } \\
\text { Wilderness }\end{array}$ & $L, D$ & Cf & & + & 1982 & 1584233 \\
\hline 7 & & $\begin{array}{c}\text { Shark Bay, Western } \\
\text { Australia }\end{array}$ & L & Bs & + & & 1991 & 2200902 \\
\hline 8 & & $\begin{array}{l}\text { Australian Fossil } \\
\text { Mammal Sites } \\
\text { (Riversleigh, } \\
\text { Naracoorte) }\end{array}$ & $L, D$ & Bs & + & & 1994 & 10300 \\
\hline 9 & & $\begin{array}{c}\text { Greater Blue } \\
\text { Mountains Area }\end{array}$ & L & Cf & + & & 2000 & 86200 \\
\hline 10 & USA & $\begin{array}{l}\text { Grand Canyon } \\
\text { National Park }\end{array}$ & $L, D$ & Bw & + & & 1979 & 493270 \\
\hline 11 & & $\begin{array}{l}\text { Mammoth Cave } \\
\text { National Park }\end{array}$ & L & Cf & + & & 1981 & 21191 \\
\hline 12 & & $\begin{array}{c}\text { Carlsbad Caverns } \\
\text { National Park }\end{array}$ & L & Bs & + & & 1995 & 18926 \\
\hline 13 & Canada & $\begin{array}{c}\text { Nahanni National } \\
\text { Park }\end{array}$ & L, D & Df & + & & 1978 & 476560 \\
\hline 14 & & $\begin{array}{l}\text { Canadian Rocky } \\
\text { Mountain Parks }\end{array}$ & $L, D$ & Df & + & & 1984 & 2299104 \\
\hline 15 & Cuba & $\begin{array}{c}\text { Desembarco del } \\
\text { Granma National } \\
\text { Park }\end{array}$ & L & $A w$ & + & & 1999 & 41863 \\
\hline 16 & & $\begin{array}{c}\text { Alejandro de } \\
\text { Humboldt National } \\
\text { Park }\end{array}$ & L & Aw & + & & 2001 & 71140 \\
\hline
\end{tabular}




\begin{tabular}{|c|c|c|c|c|c|c|c|c|}
\hline 17 & Thailand & $\begin{array}{c}\text { Thungyai-Huai Kha } \\
\text { Khaeng Wild life } \\
\text { Sanctuaries }\end{array}$ & L & Am & + & & 1991 & 622200 \\
\hline 18 & & $\begin{array}{c}\text { Dong Phayayen- } \\
\text { Khao Yai Forest } \\
\text { Complex }\end{array}$ & L & Am & + & & 2005 & 615500 \\
\hline 19 & Vietnam & Ha Long Bay & L & Am & + & & 1994,2000 & 150000 \\
\hline 20 & & $\begin{array}{l}\text { Phong Nha-Ke } \\
\text { Bang National Park }\end{array}$ & L & Am & + & & 2003,2015 & 85754 \\
\hline 21 & Bulgaria & Pirin National Park & M & $\mathrm{Cf}$ & + & & 1983 & 38350 \\
\hline 22 & Croatia & $\begin{array}{l}\text { Plitvice Lakes } \\
\text { National Park }\end{array}$ & L & $\mathrm{Cf}$ & + & & 1979,2000 & 29482 \\
\hline 23 & Indonesia & $\begin{array}{l}\text { Lorentz National } \\
\text { Park }\end{array}$ & L & Af & + & & 1999 & 2350000 \\
\hline 24 & Madagascar & $\begin{array}{l}\text { Tsingy de } \\
\text { Bemaraha Strict } \\
\text { Nature Reserve }\end{array}$ & L & Aw & + & & 1990 & 152000 \\
\hline 25 & Malaysia & $\begin{array}{l}\text { Gunung Mulu } \\
\text { National Park }\end{array}$ & L & Af & + & & 2000 & 52864 \\
\hline 26 & Mexico & Sian Ka'an & L & Aw & + & & 1987 & 528000 \\
\hline 27 & Montenegro & $\begin{array}{l}\text { Durmitor National } \\
\text { Park }\end{array}$ & L & $\mathrm{Cf}$ & + & & 1980,2005 & 32100 \\
\hline 28 & Philippines & $\begin{array}{l}\text { Puerto-Princesa } \\
\text { Subterranean River } \\
\text { National Park }\end{array}$ & L & Aw & + & & 1999 & 22202 \\
\hline 29 & $\begin{array}{l}\text { Republic of } \\
\text { Korea }\end{array}$ & $\begin{array}{c}\text { Jeju Volcanic } \\
\text { Islands and Lava } \\
\text { Tubes }\end{array}$ & $L, D$ & $\mathrm{Cf}$ & + & & 2007 & 9475 \\
\hline 30 & Russia & $\begin{array}{l}\text { Lena Pillars Nature } \\
\text { Park }\end{array}$ & $L, D$ & Df & + & & 2012,2015 & 1387000 \\
\hline 31 & Seyshelles & Aldabra Atoll & L & Af & + & & 1982 & 35000 \\
\hline 32 & Slovenia & Škocjan Caves & L & $\mathrm{Cf}$ & + & & 1986 & 413 \\
\hline 33 & $\begin{array}{l}\text { Solomon } \\
\text { Islands }\end{array}$ & East Rennell & L & Af & + & & 1998 & 37000 \\
\hline 34 & Turkey & $\begin{array}{l}\text { Hierapolis- } \\
\text { Pamukkale }\end{array}$ & L & Cs & & + & 1988 & 1077 \\
\hline 35 & $\begin{array}{l}\text { United } \\
\text { Kigdom }\end{array}$ & Henderson Island & L & $\mathrm{Cf}$ & + & & 1988 & 3700 \\
\hline 36 & $\begin{array}{l}\text { Hungary- } \\
\text { Slovakia }\end{array}$ & $\begin{array}{c}\text { Caves of Aggtelek } \\
\text { Karst and Slovak } \\
\text { Karst }\end{array}$ & L & Cf & + & & 1995,2000 & 56651 \\
\hline 37 & $\begin{array}{l}\text { France- } \\
\text { Spain }\end{array}$ & $\begin{array}{c}\text { Pyrénées -Mount } \\
\text { Perdu }\end{array}$ & $L$ & Cf & & + & 1997, 1999 & 30639 \\
\hline
\end{tabular}


parentheses correspond to that represented in Table 1 and shown on Fig. 1) is the first karst natural object inscribed on the UNESCO List in 1978.

As can be seen from Table 1 and Fig. 1, the largest number of the World Heritage Sites is situated in the China - five natural areas nominated: (1-5). All of them belong to the areas of karst development in the central and southern parts of the region researched. According to M.M. Sweeting (Sweeting 1995), the karst occupies more than $15 \%$ of the China territory, that is the reason that the numerous works of the Institute of Karst Geology (Guilin, Guangxi) are devoted to the karst processes study. In December 2008 this Institute was renamed to the International Research Center on Karst under the Auspices of UNESCO where the substantial attention is focused on the exploration of karst manifestations universal significance.

Four unique karst objects are located in the Australia: (6-9), therewith the World Heritage Site "Australian Fossil Mammal Sites (Riversleigh, Naracoorte)" (8) consists in two parts, the northern and southern, united in the one nomination. Since the end of last century the Australian colleagues have paid much attention to the protection of karst areas, in particular to the ones having the property of the World Heritage (Middleton 2016; Watson et al. 1997).

Three outstanding karst properties are found in the United States: (10-12), two ones are distinguished in the Canada: (13-14), Cuba: (15-16), Thailand: (17-18) as well as in the Vietnam: (19-20). In fourteen countries Bulgaria, Great Britain, Indonesia, Korea, Madagascar, Malaysia, Mexico, Seychelles, Slovenia (Fig. 3), Solomon Islands, Turkey, the Philippines, Croatia and Montenegro there is the one karst site with a high international status of UNESCO, two of which are the cross-border, belonging to two countries simultaneously: the Hungary and the Slovakia: (36) as well as the France and the Spain: (37)

As it was indicated in the Table 1, the following regularity is observed in distribution of UNESCO karst properties by the parts of the world: in Asia - 16 sites with a total area protected of $7241 \mathrm{~km}^{2}$ (7 241009 ha), in North America - respectively 8 and $3950 \mathrm{~km}^{2}$ (3 950054 ha), in Europe - 7 and 191 (191 335), in Australia - 4 and 3882 (3 881 635) and in Africa - 2 and $1870 \mathrm{~km}^{2}(1870000)$.
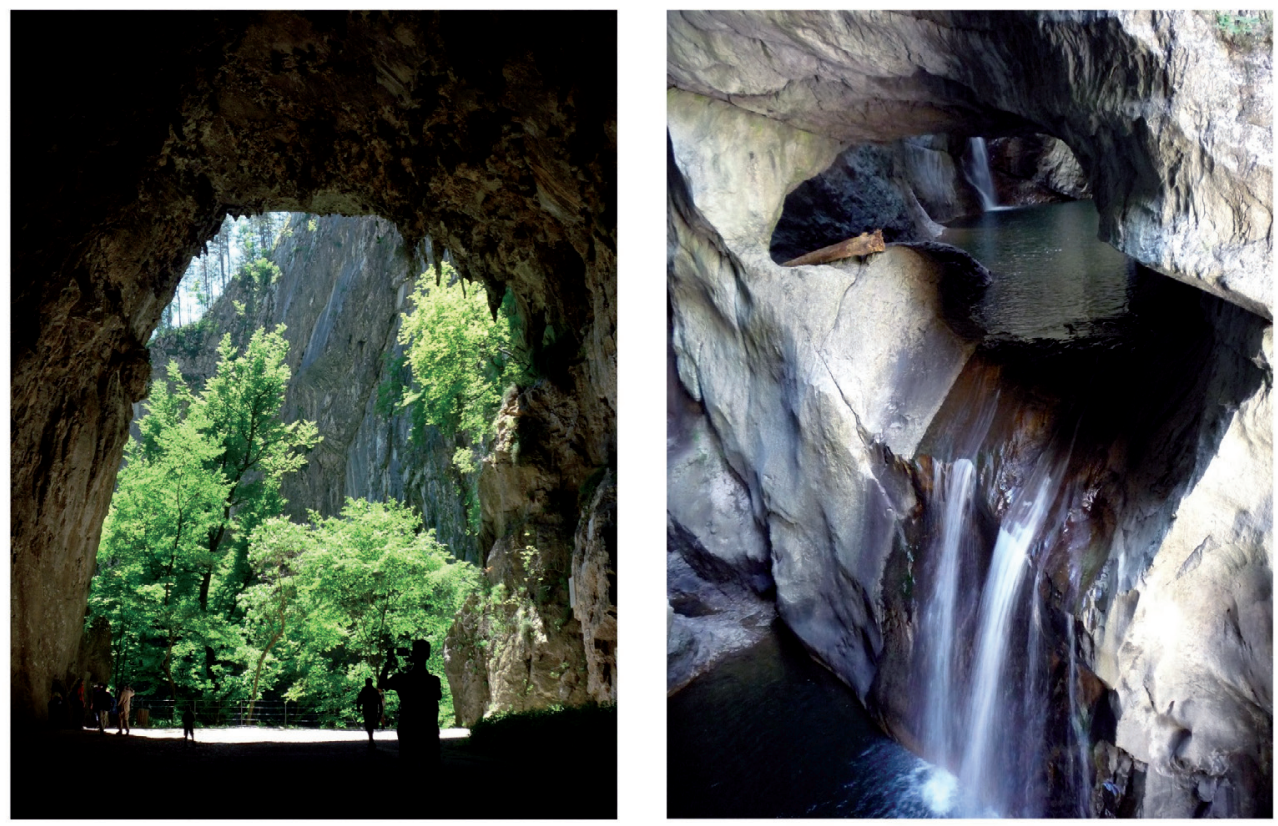

Fig. 3. Škocjan Cave (Slovenia): to the left - entrance to the cavern, to the right underground waterfalls (photos A. Trofimov) 
By lithology, all World Karst Heritage properties are characterized by karst development in carbonate rocks (Table1): the overwhelming majority of the sites (26 ones) are belonging to the regions of limestone outcrops (L in Table 1), 10 nominations hold for dolomites ( $D$ in Table 1 ) and limestones and 1 property is located in the frame work of limestones, dolomites and marbles ( $M$ in Table 1). The regions of evaporate karst (in halites, gyps, anhydrites, etc.) are not represented at the World Karst Heritage List on the whole, although according to the explorations realized, for example, by V.N. Dublyansky, G.N. Dublyanskaya (2007), the total area of karst rocks is estimated at 51 millions $\mathrm{km}^{2}$, of which the limestones occupies the area to 40 millions $\mathrm{km} 2$, gyps and anhydrites - 7 millions km2and salt - not more than 4 millions km2. Hence, the area of evaporate karst development constitutes more than $20 \%$ of the total karst manifestation areas on the globe.

Predominance of warm climatic conditions for karst development is the second important feature of UNESCO's karst properties (Table 1): 34 cases. Only 3 nominations refer to a cold climate. Four World Heritage Sites (23), (25), (31), (33) are described by the climate of tropical forests /Af - here and further by Latin letters is the type of climate according to V.P. Köppen (Drozdov et al. 1989)/; also four properties: (17-20) are characterized by the transitional climate: from the climate of the tropical forests to the climate of the savanna /Am/, but the climate of savanna /Aw/ is observed for five areas: (15-16), (24), (26) and (28). The climate of deserts /Bw/ is noted only for the one site: (10), but the climate of the steppes /Bs/ is mentioned for the three properties: (7-8) and (12). One site nominated has been marked by a warm temperate (with a dry summer) climate /Cs/: (34), and three properties: $(1,2,4)$ are described by the same warm temperate climate, but with a dry winter /CW/. The warm temperate climate with uniform humidification /Cf/ has the most spread for the World Heritage karst areas: 13 sites. Cold temperate climate with uniform humidification /Df/ is appropriate for three properties: (13), (14) and (30).
The advisability of the new nominations to reflect the karst development «in cold regions, arid/semi-arid regions and tropical oceans regions, and to identify evaporite karst sites of outstanding universal value", was underlined by P. Williams (Williams 2008).

\section{RUSSIAN WORLD KARST HERITAGE}

As it was shown above, currently only one Russian natural karst object was inscribed on the List of World Heritage: the Lena Pillars Nature Park (30) within which the different forms of karst relief have been occurred. The Nature Park Lena Pillars gained its high status precisely as an example of the region where the universal outstanding type of the karst -frozen ground karst, is widely spread (Butorin et al. 2012): on the 2nd of July 2012 - for the Buotamsky (Botomsky) site with an area of 1272150 hectares and on the 6th July 2015 - for the Sinsky site with an area of 114850 ha.

The karst of the Lena Pillars Nature Park (NPLP) is developed in a cold dry continental climate: the mean annual air temperature in the area reach $-9.8^{\circ} \mathrm{C}$ with a mean annual precipitation of $249 \mathrm{~mm}$. The karst is developed in the Lower Cambrian limestones and dolomites of 400-500 m thick, covered by cryogenic-eolian deposits in the valley band of the Prilenskoe Plateau and on the watersheds of the Lena, Buotama and Sinyaya Rivers. The area of exploration is characterized by a high degree of rocks fracturing, mainly sublatitudinal and submeridional directions (Butorin et al. 2012; Korzhuev 1961).

The uniqueness of the NPLP karst is predetermined by its development in the conditions of continuous permafrost up to $500 \mathrm{~m}$ thick, where the moisture condensation processes are the main factor of karstogenesis. On one hand, during spring and summer periods the soil layer actively condenses the water moisture from the air because of the considerable amplitudes of daily air temperature fluctuations, reaching $12.8^{\circ} \mathrm{C}$. On the other hand, the condensation of moisture occurs on the lower part of the active layer as a consequence of big 
gradients (to $7.8^{\circ} \mathrm{C}$ per $1 \mathrm{~m}$ ) between earth temperatures and lower situated perennially frozen rocks. As observed in a condenser created at the Melnikov Permafrost Institute (Siberian Branch of the Russian Academy of Sciences), $80 \mathrm{~mm}$ of water is condensed at the average in the Central Yakutia during the warm season (Shepelev 1980), constituting more than 30\% of annual precipitation. Moreover, the permafrost blocks the quick filtration of precipitation into karst massifs. Thus, the accumulation of water, which in turn, causes the karst processes, occurs on the surface. This moisture, cooled almost to zero temperatures, is distinguished by a considerable aggressiveness in relation to karst rocks: since dissolved carbon dioxide (being also a leading factor of a karstogenesis) is characterized by the greatest solubility in cold water: the $\mathrm{CO} 2$ absorption coefficient is 0.665 at the solution temperature of $30^{\circ} \mathrm{C}$, at the temperature of $15^{\circ} \mathrm{C}-1.019$ and at $0^{\circ} \mathrm{C}$ is already 1.713 (Jakucs 1973).

Numerous publications (Butorin et al. 2012; Korzhuev 1961; Rozentsvit 1948; Trofimova 2017; etc.) have been dedicated to the description of the NPLP classic karst phenomena: karren, sinkholes, dry valleys, niches, caves (Fig. 4), etc.

\section{DISCUSSION}

As it was mentioned before, 37 karst properties are currently described by a high status of an outstanding universal value on the globe. Obviously, for Russia (where 8 karst areas, 22 karst provinces, and 57 karst districts are distinguished only on the Russian Plain (Chikishev 1978)) there is a considerable potential for natural karst sites of such high status, therewith, for example, both for conditions of sulphate (karst of the Belomoro- Kuloy Plateau in the Arkhangelsk Region) and salt karst (the Kempendyay salt springs in the Yakutia), that is more the areas considered are referred to the conditions of moderately cold climate with uniform humidification (Df).

A remarkable example of a naked sulphate karst is developed in SE part of the Belomorsko-Kuloy Plateau located on the NW of the Russian Plain at 70-180 m above sea level. Lower Permian gypsums and anhydrites with a typical thickness 40-70 $\mathrm{m}$ are exposed here. The rocks have practically a monomineral composition: 95$98 \%$ consisting of $\mathrm{CaSO} 4 \times 2 \mathrm{H} 2 \mathrm{O}$ (The Karst... 2011).
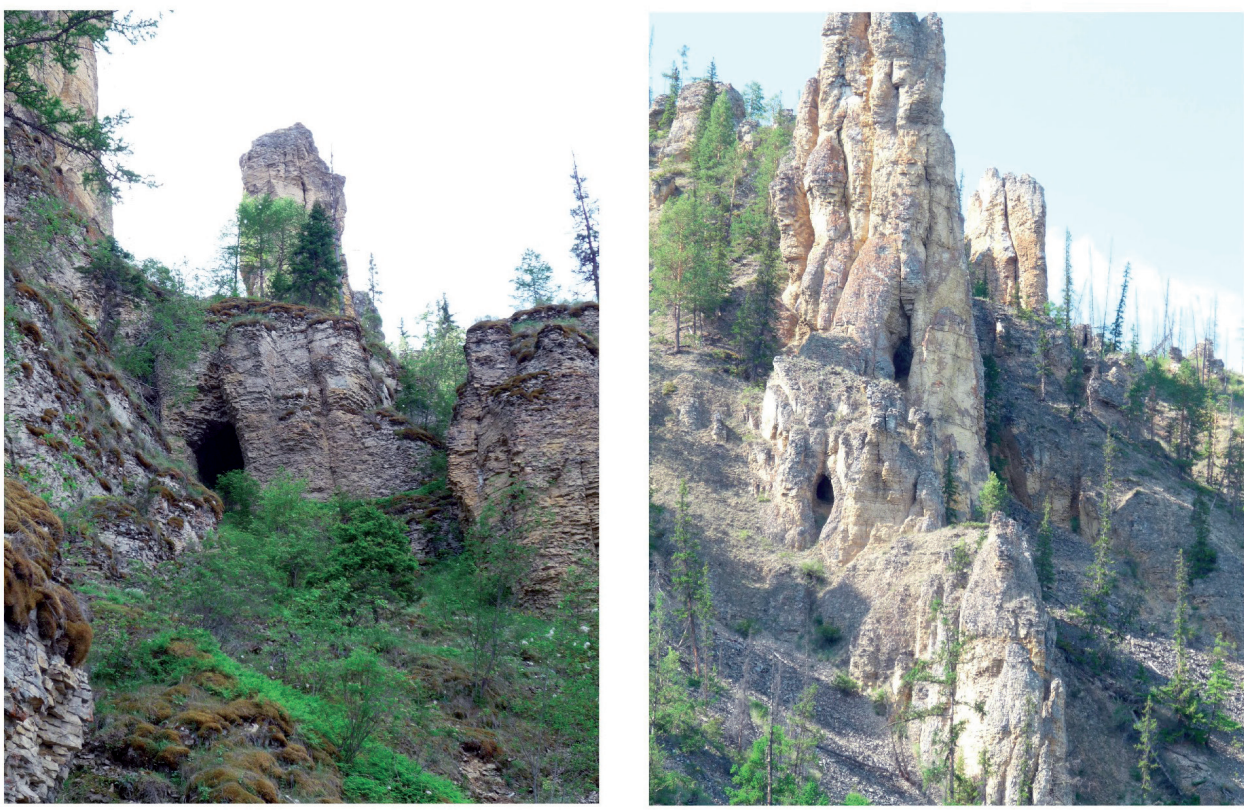

Fig. 4. Caves of the Sinyaya River Valley: to the left - in the locality Peschanka, to the right - near a mouth of the River Silbakh (photos A. Trofimov) 
The sulphate rocks of the BelomorskoKuloy Plateau are considerably karstified especially in wide-spread karst fields, socalled "shelopnyaky" by a local dialect where a density of the superficial karst forms (sinkholes, karst basins, small flat-bottom valleys) reaches extremely unique values: more than 3000 (The karst... 2011) per 1 km2. As it is described by A.G. Chikishev (1965): "Sometimes the crests separating the sinkholes are such narrow that it is impossible to across theirs without risk of falling down. The diameter of sinkholes is varied from 5 to $50 \mathrm{~m}$ and the depth is changed between 1.5-15.0 m".

Underground forms of sulphate karst are developed in the frame work of the Belomorsko-Kuloy Plateau very intensively too. So, 16 caverns by a total length of 22,856 km (The Karst... 2011) are described in the Kulogorsky area among which the famous Kulogorskaya-Troya Cave having 17 $\mathrm{km}$ of a length at amplitude to $18 \mathrm{~m}$. For the first time this underground cavity was visited by Academician A.G. Schrenk in 1837 enthusiastically described the delightful ice formations of the cavern (Schrenk 1848).

At the beginning of the 21st century another ice cave in gypsum - Kungurskaya Cave (by total length of $5,6 \mathrm{~km}$ at $27 \mathrm{~m}$ of the depth) was proposed by the Russian karstologists for the inclusion on the World Heritage List, moreover the nomination for this cavern was written in 2006. But this property wasn't supported by the experts of the IUCN. The main reason is the artificial tunnel created in underground cavity last century which changed considerably the natural conditions of underground system.

In terms of salt karst, extremely unique natural phenomenon occurs each winter in the Kempendyay River Valley (right tributary of the Viluy River, East-Siberian Platform) where the numerous Kempendyay salt karstic springs characterizing by a high salinity - nearly $317 \mathrm{~g} / \mathrm{l}$ (a real pickle) - are situated. In the winter the salt aufeises in the form of ice hillocks by a height of 5-7 $\mathrm{m}$ and up to tens of meters in diameter are formed near the outputs of the springs.
Karstic salt aufeises are composed of hexagonal plate and prismatic needle crystals of hydrohalite $(\mathrm{NaCl} \times 2 \mathrm{H} 2 \mathrm{O})$ precipitated (upfrozen) from the pickles at the negative temperatures (starting from $\left.-1,0^{\circ} \mathrm{C}\right)$. The ice hillocks exist only in the cold half of the year since the melting point of a hydrohalite is positive namely $+0.1^{\circ} \mathrm{C}$. At the transition of air temperatures to positive values the ice hillocks disintegrate: a part of crystallized water evaporates, a part of that runs and only upfrozen waterless pure table "ice" salt (consist of $\mathrm{NaCl}$ to the extent of $98,668 \%$ ) remain in situ being widely used by a local Yakut population beginning in 1640 (Uzemblo 1966).

First the description of the «ice» salt of the Kempendyay salt karstic springs was realized in 1828 by geologist I. Tchaikovsky (the father of the Great Russian composer P. I. Tchaikovsky). He noted that in summer period «winter crystals are destroyed and turn into a fine salt dust of the purest whiteness... which is can be taken and put in bags without any difficulty» (Dzens-Litovsky 1966).

The necessity of the researches, related with the preparation of new nominations for the Russian karst sites is determined by the anthropogenic pressure which is growing every year to karst landscapes being very fragile and vulnerable. For example, 2 July 2012 the above-described Buotamsky site of the Nature Park Lena Pillars was inscribed on the World Heritage List during the 36th session of the UNESCO but it is in the summer of 2012 in the Valley of Sinyaya (the Sinsky site of NPLP) a gabbro-diorite quarry was found in a few kilometers from the mouth of its right tributary: River Billyakh. However, already in 2013 the preparation of Sinsky site nomination was started under the influence of local population and at the support of the direction of the natural park. In fact the prompt work of Natural Heritage Protection Fund of Russia saved the nature of the Valley of Sinyaya from the destruction: after 39th session of UNESCO (25 June-10 July 2015) for which the Sinsky site nomination was supported almost unanimously, the further exploitation of the quarry was completely stopped. 


\section{CONCLUSIONS}

1. So far, 37 karst properties were inscribed on the List of UNESCO World Natural Heritage starting from 1978.

2. The World Karst Natural Heritage has been distributed by the parts of the World in the following order: in the Asia - 16 sites, in the North America - 8, in the Europe - 7, in the Australia - 4 and in the Africa - 2.

3. It seems advisable for Russia (as well as on the whole for the globe) to prepare the new nominations for the unique outstanding karst of the sites located in the evaporite karst, more than that in conditions of cold climate. Two new nominations are proposed for the first step: sulphate karst of the Belomoro- Kuloy Plateau in the Arkhangelsk Region and salt karst of the Kempendyay salt springs in the Yakutia: both properties are disposed in cold climatic conditions.

\section{REFERENCES}

Butorin A., Fedorov A., Kipriyanova L., Kolosov P., Maxakovsky N., Parkhaev P., Solomonov N., Trofimova E., Zhuravlev A. (2012). Lena Pillars Nature Park. Moscow: ANNIE.

Chikishev A.G. (1978). Karst of the Russian Plain. Moscow: Nauka (in Russian).

Chikishev A.G. (1965) Kulogorskaya gypseous cave. In:Type of the karst in the URSS, Moscow: Nauka, pp. 126-138 (in Russian).

Dzens-Lithovsky A.I. (1966). Salt karst. Leningrad: Nedra (in Russian).

Dublyansky V.N. and Dublyanskaya G.N. (2007). Karst of the globe. Perm: Perm State University.

Gunn J. (2004). Encyclopedia of caves and karst science. New York-London:Taylor and Francis Group.

Drozdov O.A., Vasiliev V.E., Kobisheva N.V., Raevsky A.N., Smekalova L.K., Shkolny E.P. (1989). Climatology. Leningrad: Hydrometeoizdat (in Russian).

Jakucs L. (1973). The karstic corrosion of naturally occurring limestone in the geomorphology of our age. IGU Symp. on Karst Morphogenesis, Budapest, Vol. 3, pp. 52-121.

Korzhuev S.S. (1961). Ground frozen karst of the Srednego Prileniya and some peculiarities of its manifestations. In: Regional karstology. Moscow, USSR Academy of Sciences, pp. 207-220 (in Russian).

Middleton G.J. (2016). Necessary qualities in legislation to protect karst areas. Zeitschrift für Geomorphologie. Vol. 60, Suppl. 2, pp. 337-352.

Rozentsvit A.O. (1948). Batomay stone "Pillars" on the River Lena. Proceedings of the AllRussian Geographical Society, No. 1, pp. 85-90 (in Russian).

Shepelev V.V. (1980).The role of condensation processes in alimentation of frozen zone underground waters. In Interrelation of superficial and underground waters in frozen zone. Yakutsk, Permafrost Institute of the Siberian Branch of the USSR Academy of Sciences, pp. 4356 (in Russian).

Schrenk A.G. (1848). Reise nach dem Nordosten des europäischen Russlands, durch die Tundren der Samojeden, aumarktischen Uralgebirge. Dorpat: Heinrich Laakmann (in German). 
Sweeting M.M. (1995). Karst in China. Berlin-Heidelberg-New York: Springer.

The Karst Pinega region (Russia) (2011). The guide book of the International Conference dedicated to the 300th Anniversary of the birth of M.V. Lomonosov "Northern Karst systems in our changing environments" 5-11 September 2011, Golubino-Pinega (in Russian).

Trofimova E.V. (2017). Surprising karst in the Valley of Sinyaya. Nature, 1, pp. 48-54 (in Russian).

Trofimova E., Hada A. (2016). Location, nature and extent of karst environments at a global scale. Zeitschrift für Geomorphologie, Vol. 60, Suppl. Issue 2, pp. 17-33.

Uzemblo V.V. (1966). Salt deposits and salt manifestations of the Eastern regions of the USSR In: Proceedings of Scientific research institute of salt industry, Is. 12(20), pp. 204-218 (in Russian).

Williams, P.W. (2008). World Heritage Caves and Karst. A Thematic Study. Gland, WCPA, No 2.

World Heritage Information Kit (2008). Paris: UNESCO World Heritage Centre.

Watson J., Hamilton-Smith E., Gillieson D. and Kiernan K. (1997). Guide for Cave and Karst Protection. Gland, IUCN.

\section{AUTHORS}

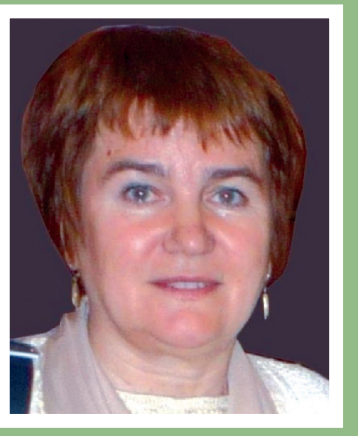

Elena V. Trofimova, PhD, is Senior Researcher of the Institute of Geography of the Russian Academy of Sciences. Karst and caves are at the focus of her explorations. She is the author of more than 100 scientific publications. 